\title{
LARVAL STAGES OF THE BLUE SWIMMER CRAB, PORTUNUS PELAGICUS (LINNAEUS, 1758) (DECAPODA, BRACHYURA)
}

\author{
BY \\ JOSE JOSILEEN ${ }^{1}$ ) and N. G. MENON \\ Central Marine Fisheries Research Institute, P.O. Box 1603, Ernakulam, Cochin 682 018, Kerala, \\ India
}

\begin{abstract}
Larvae of Portunus pelagicus (Linnaeus, 1758) were reared in the laboratory on hatching from wild ovigerous females collected from Palk Bay, southeast India. The larval stages included four zoeal stages and one megalopa. The megalopa moulted to the first crab instar. The zoeae and megalopa were very similar to those of other portunids. The duration of each of the first two zoeal stages was 3-4 days, the following two stages 2-3 days, and the megalopa 3-5 days, reaching the first crab stage in 15-17 days. All zoeal and megalopal stages are described in detail and are documented with illustrations.
\end{abstract}

\section{RÉSUMÉ}

Des larves de Portunus pelagicus (Linnaeus, 1758) ont été élevées au laboratoire, provenant de femelles ovigères sauvages collectées à Palk Bay, au sud-est de l'Inde. Les stades larvaires comprenaient quatre stades zoés et un stade mégalope. La mégalope a mué en un premier stade crabe. Les stades zoés et le stade mégalope étaient très similaires à ceux des autres Portunidae. La durée de chacun des deux premiers stades zoés était de 3-4 jours, les deux stades suivantes de 2-3 jours, et le stade mégalope de 3-5 jours, atteignant le premier stade crabe en 15-17 jours. Tous les stades zoés et mégalopes sont décrits en détail et illustrés.

\section{INTRODUCTION}

The blue swimmer crab, Portunus pelagicus (Linnaeus, 1758) is the major marine crab species landed in India, and it supports a good fishery in Palk Bay and the Gulf of Mannar along the southeastern coast. Though it is caught commercially, a study on its complete larval development is not available. Earlier works on larval development by Prasad \& Tampi (1953), Chhapgar (1956), Ameer Hamsa (1982), and Raman et al. (1987), are incomplete with respect to detailed descriptions of

1) e-mail: joslinjoys@ rediffmail.com 
diagnostic features of each stage. A detailed account of all larval stages with descriptions of all appendages is given herein. This paper consequently deals with the complete larval history of $P$. pelagicus, hatched and reared in the laboratory, which will be useful for seed production and farming in the future.

\section{MATERIALS AND METHODS}

Berried crabs and hatching. - Live berried females were collected from Palk Bay trawler catches, off Mandapam $\left(9^{\circ} 20-25^{\prime} \mathrm{N} 79^{\circ} 5-10^{\prime} \mathrm{E}\right)$, and brought to the laboratory in plastic cans provided with good aeration. They were maintained in 1500 -litre capacity fibre glass tanks at a salinity of $35 \pm 1 \mathrm{ppt}, \mathrm{pH} 8.2 \pm 0.1$, and temperature $28 \pm 2^{\circ} \mathrm{C}$, with continuous diffused aeration. Gravity sand-filtered seawater, passed through $1 \mu \mathrm{m}$ filter bags, was used for the entire rearing operation, and $50 \%$ of the water was changed once daily. Fresh clam meat was given as food to crabs with eggs in early stages, and crabs with advanced eggs were not fed, since such crabs do not feed. When the eggs became deep grey in colour, the mother crab was transferred to a hatching tank having similar environmental conditions.

Larval rearing. - After hatching, healthy active zoeae were collected and stocked in 10 litre glass beakers at a stocking density of $501^{-1}$, with a water quality equal to that of the hatching seawater. A combination of live food, i.e., diatoms, zooplankton, and inert prawn-egg custard, was provided to the various larval stages. In zoea I and II, mixed diatoms, chiefly Chaetoceros spp., and the rotifer Brachionus plicatilis Müller, 1786, were given. In zoea III and IV, rotifers and Artemia salina (Linnaeus, 1758), were provided. From zoea IV onwards, diatoms were not added to the rearing beakers. During the megalopa stage, the cladoceran, Moina micrura Kurz, 1874, and prawn-egg custard were provided. Daily, 50-60\% of the water was changed and fresh live food was added to the culture tank. The concentrations of algae, rotifers, Artemia, and Moina in the rearing medium were 25000/ml, 20-25/ml, 5-10/ml, and 3-5/ml, respectively. Prawn-egg custard was macerated and filtered through a $350 \mu \mathrm{m}$ mesh sieve, thoroughly washed in filtered sea water, and only the residue was added to the beakers, at the rate of $0.1 \mathrm{~g} /$ beaker.

The beakers with larvae were observed daily for successive developmental stages and exuviae. Camera lucida drawings of all zoeal and megalopal stages were made from preserved larvae, and detailed drawings were drawn from dissected appendages.

\section{RESULTS}

The larval development of Portunus pelagicus includes four zoeal stages and a megalopa. The megalopa stage metamorphoses into the crab stage. Zoeae are of the typical brachygnath type. Each zoea has a long rostrum, a dorsal spine, and a pair of 

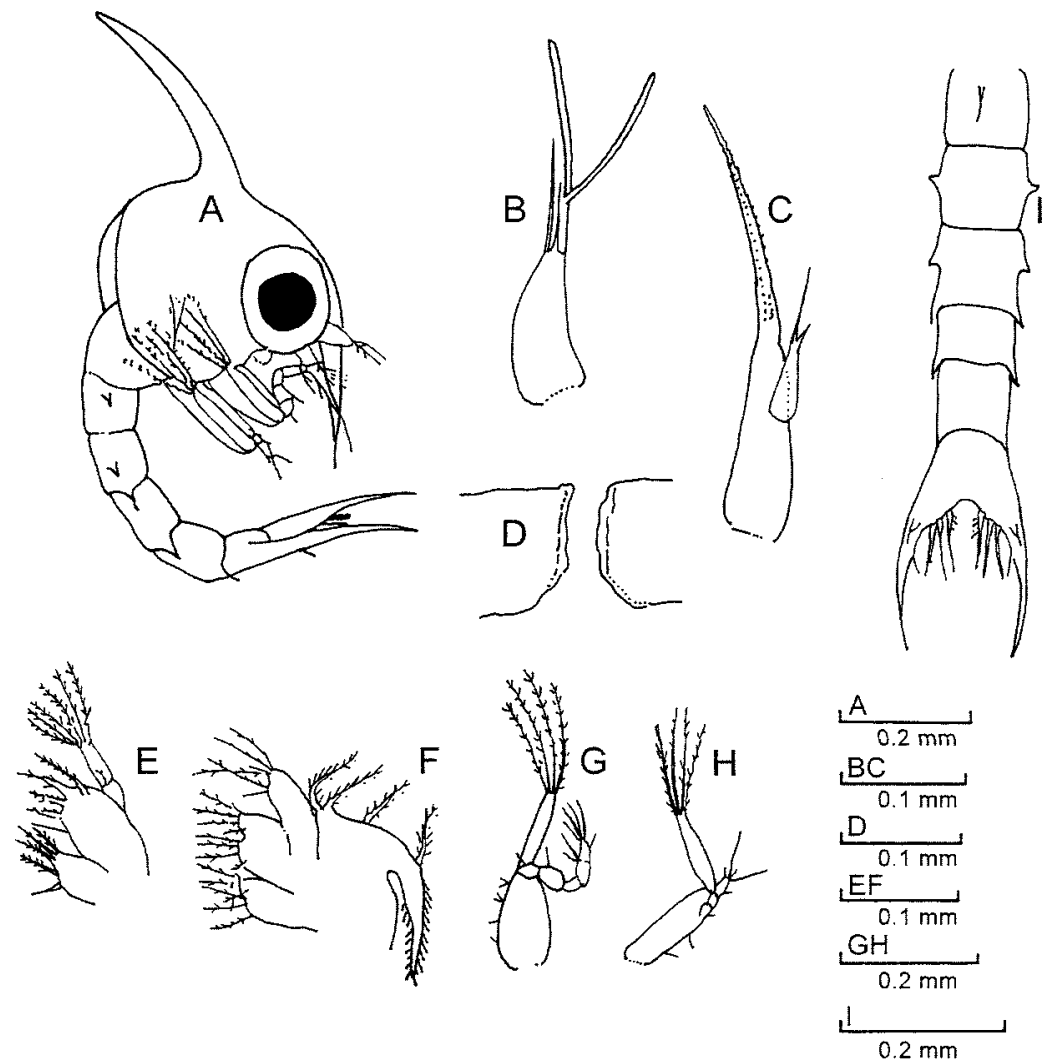

Fig. 1. Portunus pelagicus (Linnaeus, 1758), first zoea. A, whole animal, lateral view; B, antennule; C, antenna; D, mandible; E, maxillule; F, maxilla; G, first maxilliped; H, second maxilliped; I, abdomen with telson.

short lateral spines on the carapace. Carapace length (CL) was measured from the base of the rostral spine to the middle of the posterior border of the carapace, and abdomen-telson length (Abd-TL) from the proximal border of the first abdominal somite to the tip of the longest caudal spine. A detailed description of each larval stage is given below.

First zoea (fig. 1)

Carapace length 0.44-0.54 mm; abdomen-telson length 1.07-1.23 mm. Eyes sessile. First abdominal somite with short dorsal seta. (See fig. 1A.)

Antennule (fig. 1B) short, conical. Tip with two equally long aesthetascs and two short, unequal setae.

Antenna (fig. 1C) with long spiniform process bearing two long rows of short spines. Exopod short; single segment bears two unequal setae at distal end. 
Mandible (fig. 1D) small with broad cutting edges.

Maxillule (fig. 1E) protopod with unsegmented coxal and basal endites. Basal endite with five setae that are sparsely plumose. Coxal endite with six to seven setae.

Maxilla (fig. 1F) with bilobed coxal and basal endites; unsegmented endopod and broad scaphognathite. Each lobe of coxal endite with three plumose setae. Each lobe of basal endite bears three plumose setae of varying length. Endopod carrying four terminal and two subterminal plumose setae.

First maxilliped (fig. 1G) with protopod broad, bearing six to seven short setae on inner margin. Endopod five-segmented, bearing 1-1-0-2-5 setae (from proximal to distal). Exopod unsegmented, carrying 8 long, plumose natatory setae terminally (in lateral view only 4 are seen, as shown in the figure).

Second maxilliped (fig. 1H) with broad protopod that bears two or three short setae on inner margin. Endopod four segmented, bearing 1-1-1-5 setae. Of the five setae on the distal segment, two are more than three times as long as the others. Exopod unsegmented, bearing eight long, plumose natatory setae distally (in lateral view only 4 visible).

Abdomen (fig. 1I) five-segmented plus the telson. Second and third somites bear a short lateral knob on either side. Knobs on the second somite larger and directed anteriorly; those on third directed posteriorly. Posterior margin of each abdominal somite overlaps next. Third, fourth, and fifth somites each bear a pair of lateral spines on posterior margin, directed backwards.

Telson (fig. 1I) forked, with each fork bearing one inner and one dorsal spine. Inner margin of each fork bears three long, serrated setae.

\section{Second zoea (figs. 2-3)}

Carapace length 0.72-0.77 mm, abdomen-telson length 1.46-1.54 mm. Eyes stalked. (See fig. 2.)

Antennule (fig. 3A) with number of aesthetascs increased to five; one seta.

Antenna (fig. 3B) as in previous stage, except endopod bud longer.

Mandible (fig. 3C). More developed than in first zoea; bears corrugated ridges of thickened cuticle.

Maxillule (fig. 3D) with coxal endite with six, basal endite with 9-10 sparsely setose setae. Endopod two-segmented; proximal segment with single seta, distal segment with six setae.

Maxilla (fig. 3E) with coxal endite bilobed, each lobe with three setae. Each of basal endites with four or five setae. Endopod unsegmented, bearing four terminal and two subterminal setae. Scaphognathite bears seven plumose setae along its outer margin. In addition to these, the dorsally directed process bears three plumose setae. 


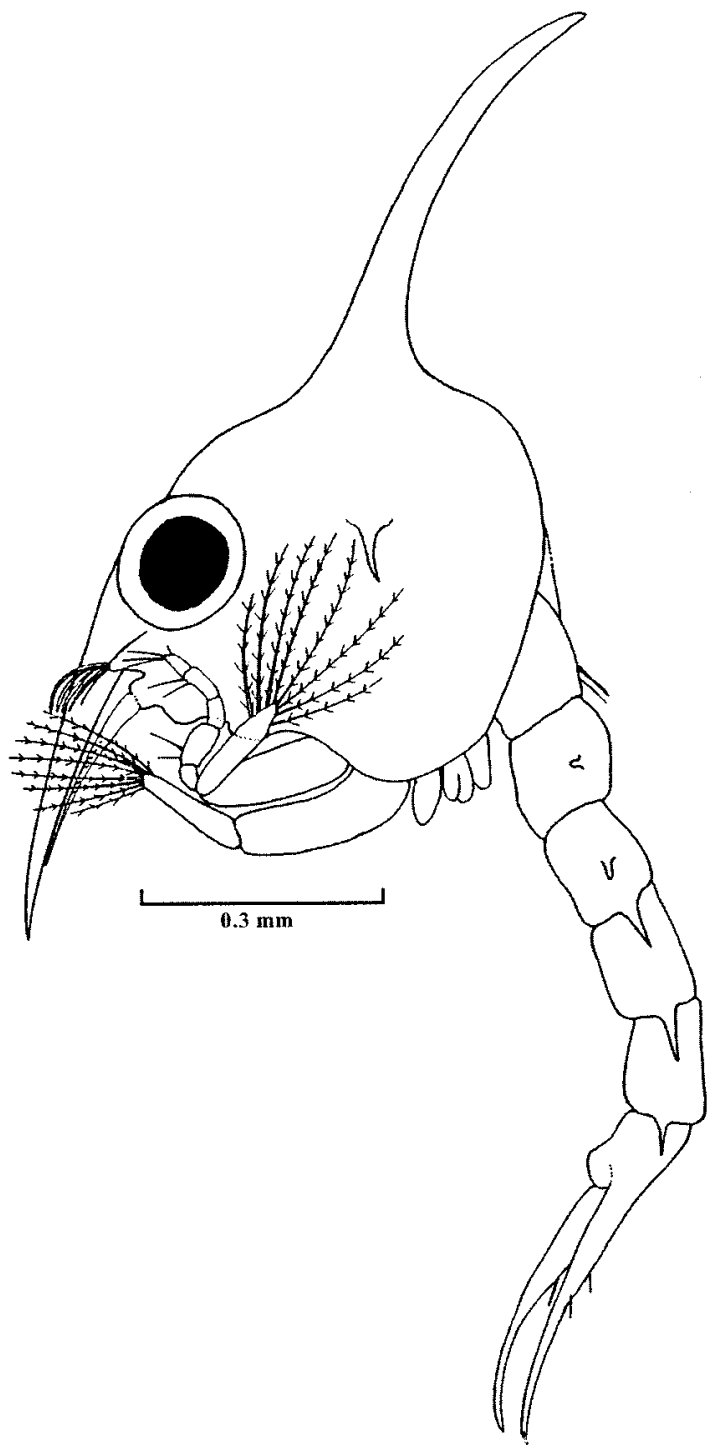

Fig. 2. Portunus pelagicus (Linnaeus, 1758), second zoea, whole specimen in lateral view.

First maxilliped (fig. 3F) with basipod broad, bearing 9-10 setae on inner margin. Endopod with 2-2-0-2-5 setae. Exopod with eight long, natatory plumose setae at distal end (4 setae shown in the figure, depicted in lateral view).

Second maxilliped (fig. 3G) basipod with three to four setae on inner margin. Endopod with 1-1-1-5-5 setae. Exopod with eight long, plumose natatory setae.

Abdomen (fig. 3H) as in previous stage, except for pair of medium-sized setae on dorsal surface of first somite. Abdominal somites 3-5 have more distinct lateral spines. 

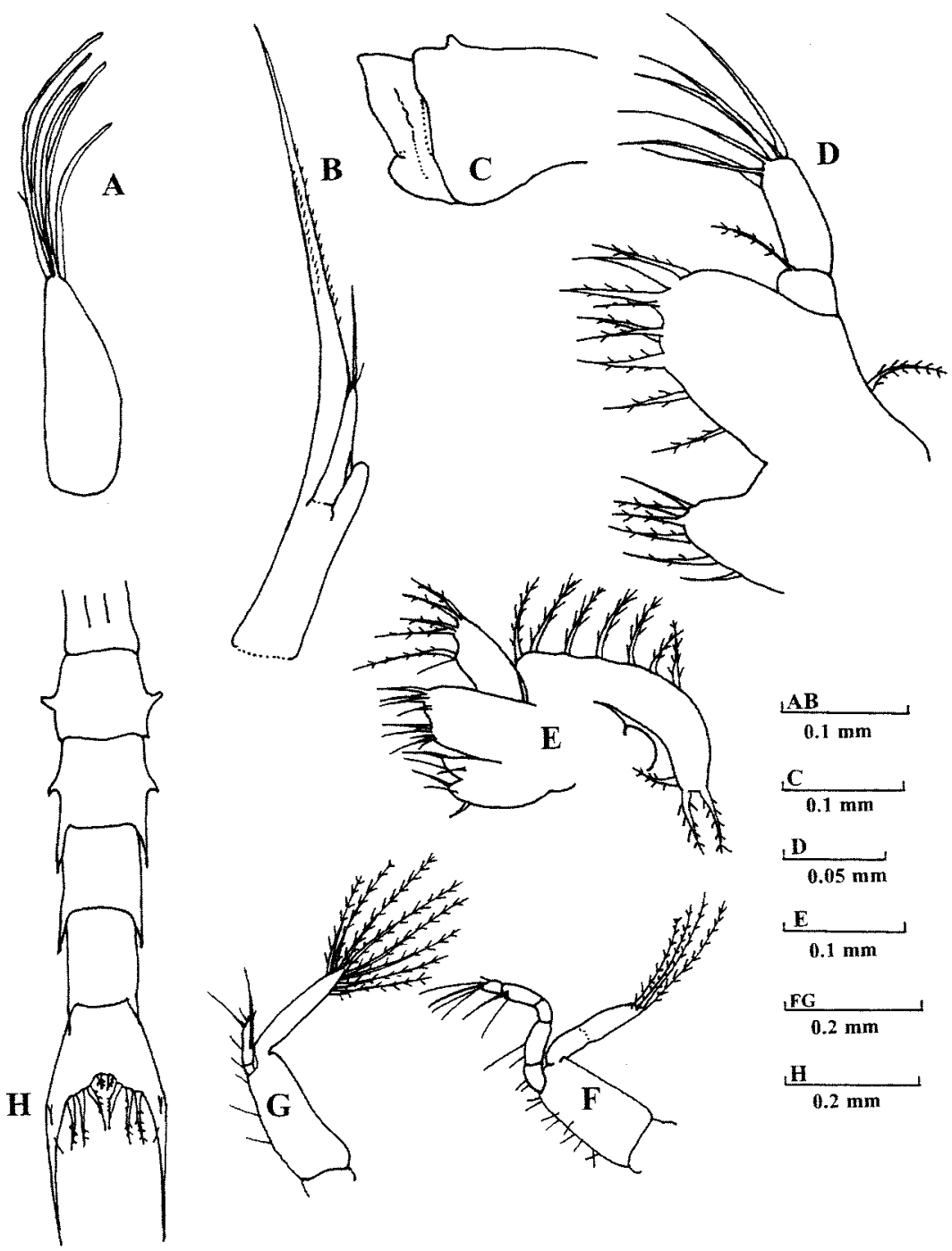

Fig. 3. Portunus pelagicus (Linnaeus, 1758), second zoea. A, antennule; B, antenna; C, mandible;

D, maxillule; E, maxilla; F, first maxilliped; G, second maxilliped; H, abdomen with telson.

Telson (fig. 3H). A pair of short, plumose setae on median margin of cleft part. Other structures as in previous stage.

Third zoea (figs. 4-5)

Carapace length 0.79-0.87 mm, abdomen-telson length 2.02-2.21 mm. (See fig. 4.) Rudimentary buds of thoracic appendages developed behind second maxilliped (fig. 5H). 


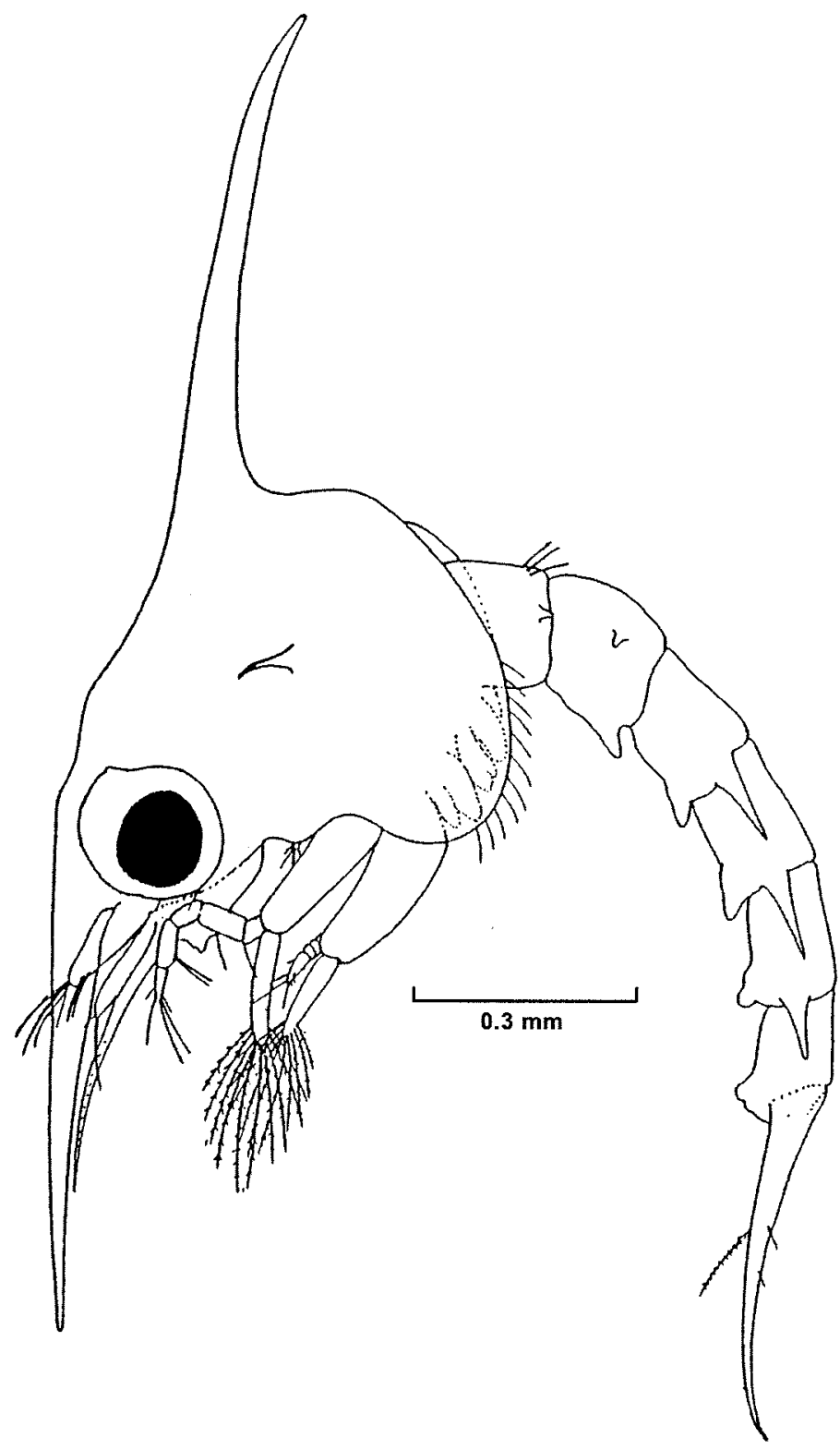

Fig. 4. Portunus pelagicus (Linnaeus, 1758), third zoea, in lateral view.

Antennule (fig. 5A) as in zoea II, but larger. Aesthetascs arranged in two groups; 4 long terminal aesthetascs and one seta, and 2 smaller subterminal aesthetascs. Antenna (fig. 5B) with endopod that has become as long as exopod.

Mandible (fig. 5C) as in zoea II, except for prominent teeth developed on cutting edges. 


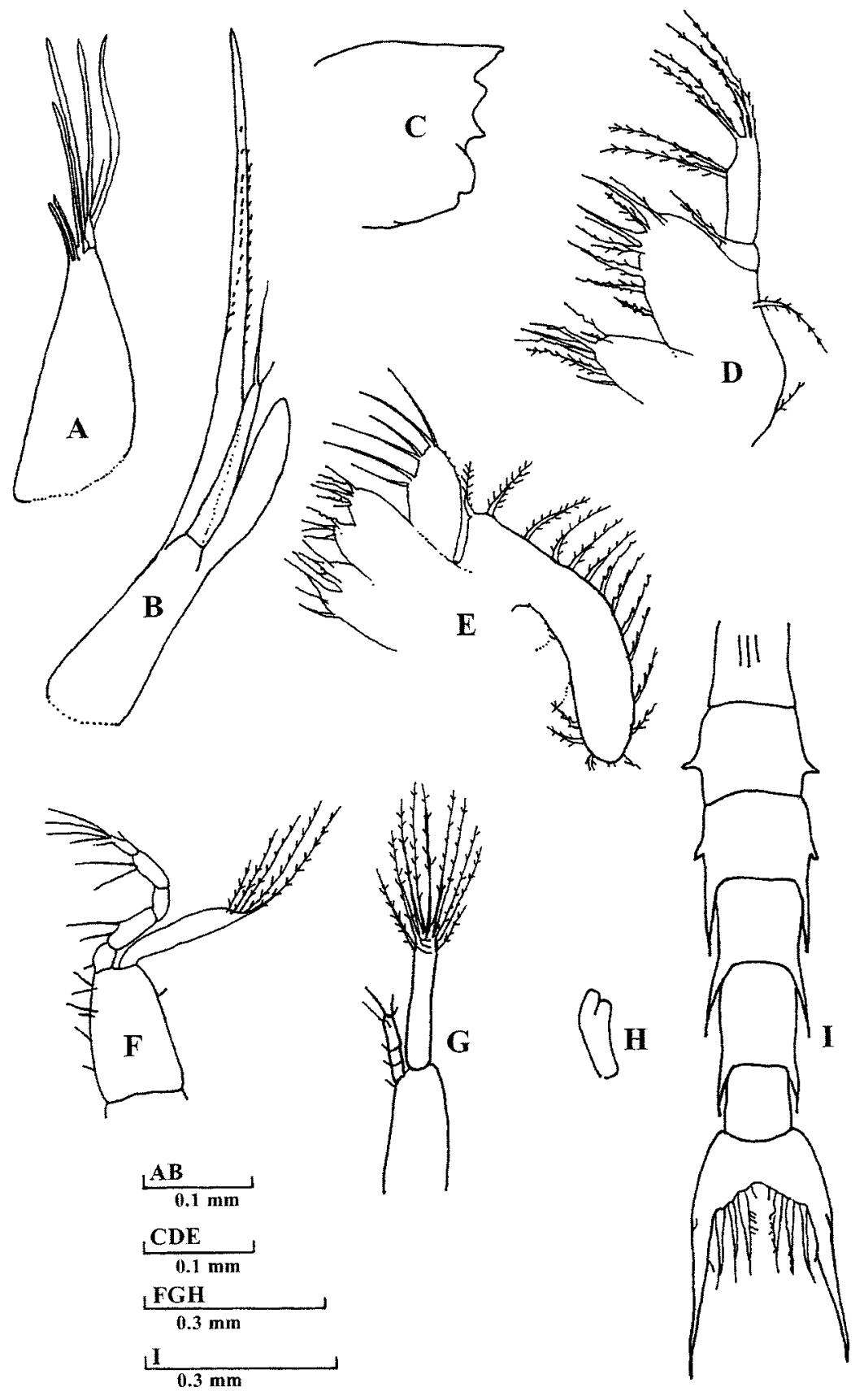

Fig. 5. Portunus pelagicus (Linnaeus, 1758), third zoea. A, antennule; B, antenna; C, mandible; $\mathrm{D}$, maxillule; E, maxilla; F, first maxilliped; $\mathrm{G}$, second maxilliped; $\mathrm{H}$, rudimentary thoracic appendage; I, abdomen with telson. 
Maxillule (fig. 5D) with coxal endite bearing 7 setae, some setose. Basipod with 10-11 setae, some short, a few setose. Endopod two-segmented. Distal segment with 4 long terminal and 2 long subterminal plumose setae. Basipod bears two plumose setae on outer margin.

Maxilla (fig. 5E). Each of coxal endites bears 3 setae, one stout. Basal endites each bear 4-6 setae, some setose. Scaphognathite with 17-18 plumose setae on outer margin.

First maxilliped (fig. 5F) longer than in previous stage. Exopod bears 8 long terminal and 2 long subterminal plumose natatory setae.

Second maxilliped (fig. 5G). Exopod with 8 long terminal and 2 long subterminal plumose natatory setae.

Abdomen (fig. 5I) 6-segmented; dorsal surface of first abdominal somite has 3 median short setae. Lateral spines on somites 3-5 longer. Paired pleopod buds at ventral posterior end of somites 2-5.

Telson (fig. 5I). Similar to that of previous stage.

\section{Fourth zoea (fig. 6)}

Carapace length 0.98-1.06 mm; abdomen-telson length 2.61-3.03 mm.

Antennule (fig. 6A) bears aestheascs in two tiers; terminally 4 aestheascs and one seta, other aesthetascs subterminal. Endopod represented by small bud.

Antenna (fig. 6B) longer than in zoea III. Endopod longer than exopod.

Mandible (fig. 6C) with size increased. Mandibular palps as small buds.

Maxillule (fig. 6D). Coxal endite with 12-13 setae, basal endite with 15-16 setae. Some setae on basal endite stout and sparsely setose. Distal segment of two-segmented endopod with 4 long terminal and 2 subterminal plumose setae; proximal segment bears one plumose seta on inner margin. Outer margin of basipod carries two short plumose setae.

Maxilla (fig. 6E). Scaphognathite expanded; 30-32 plumose setae along outer margin. Number of setae on endites increased: each coxal endite bears 4-5 setae, basal endites 7-9 setae. Endopod with six plumose setae: two terminal, two suberminal, two near middle.

First maxilliped (fig. 6F). Size increased. Endopod segments bearing 2-2-1-2-6 setae. Exopod has 12 subterminal natatory setae.

Second maxilliped (fig. 6G) unchanged except that exopod bears 4 terminal and 8 subterminal long plumose natatory setae.

Pereiopods (fig. 6H, I). First pereiopod bud with well developed chela; pereiopods 2-5 starting segmentation.

Pleopods (fig. 6J). Second to sixth pleopod buds developed. 


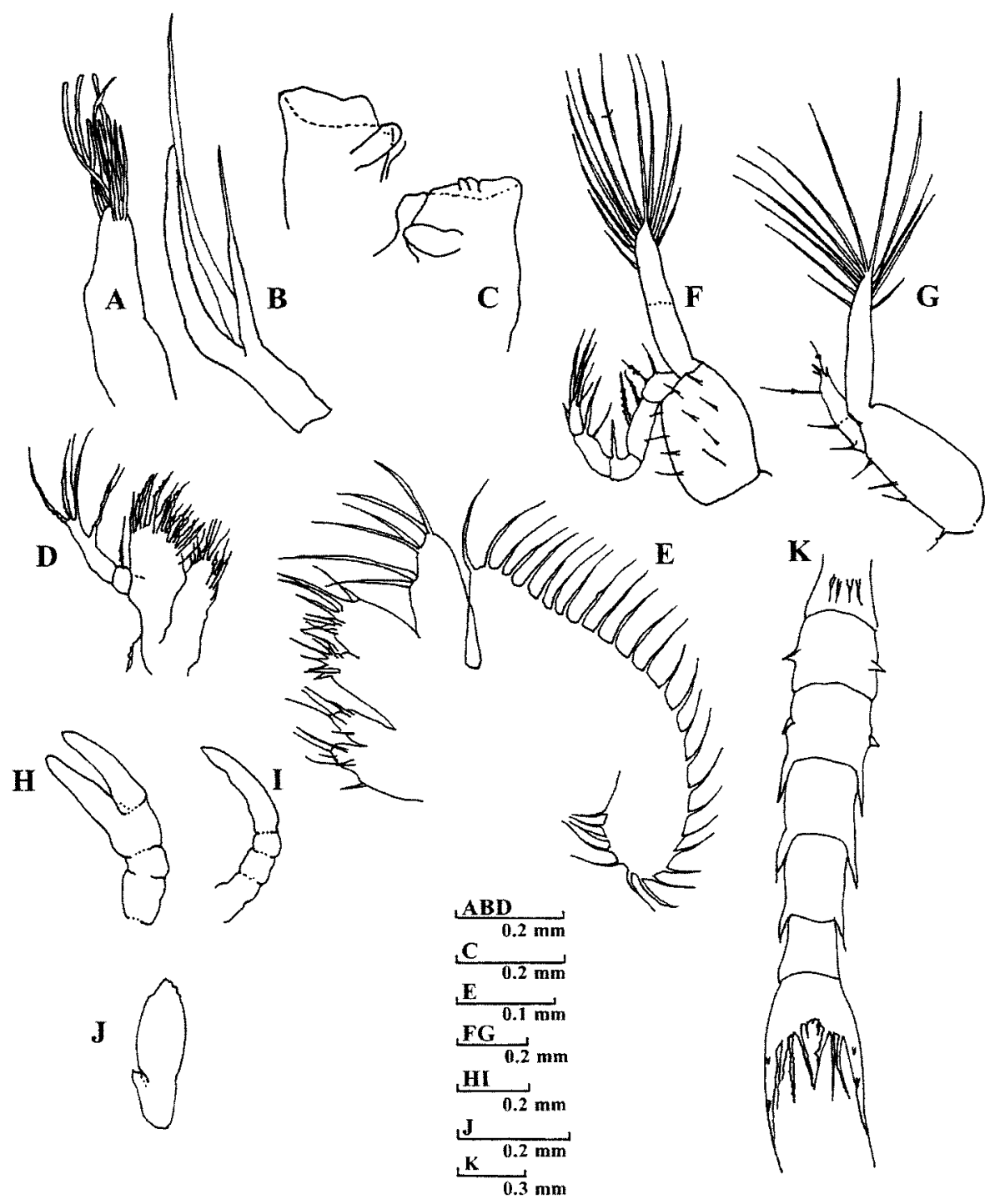

Fig. 6. Portunus pelagicus (Linnaeus, 1758), fourth zoea. A, antennule; B, antenna; C, mandible; D, maxillule; E, maxilla; F, first maxilliped; G, second maxilliped; H, first pereiopod; I, second pereiopod; J, second pleopod; K, abdomen with telson.

Abdomen (fig. 6K). Pleopod buds well developed: biramous on somites 2-5, uniramous on somite 6. Exopods of some pleopod buds with short, non-plumose setae. Dorsal surface of first abdominal somite has 4 median short setae.

Telson (fig. 6K). Similar to that of zoea III, except for additional short seta on inner margin. 


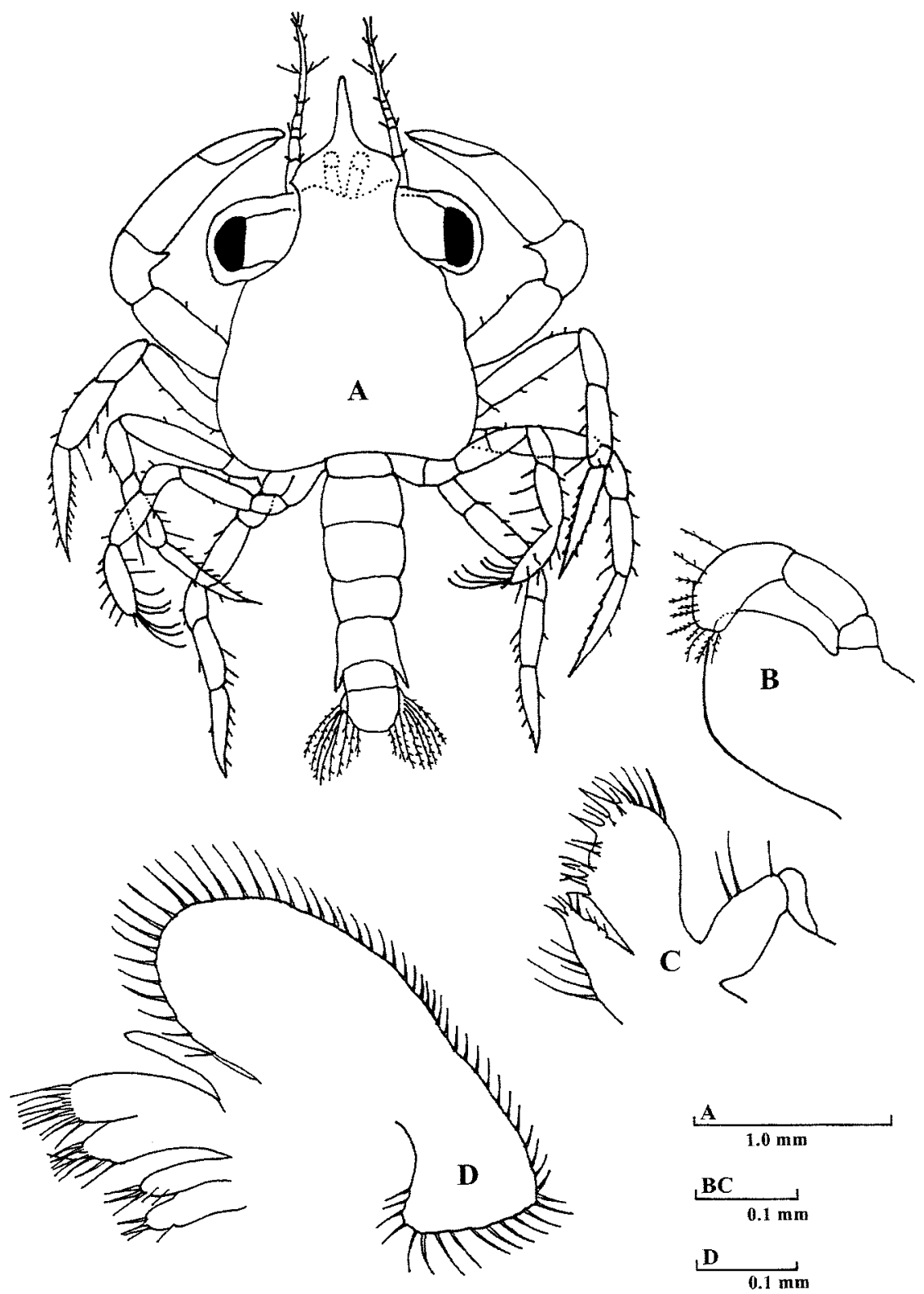

Fig. 7. Portunus pelagicus (Linnaeus, 1758), megalopa. A, whole animal, dorsal aspect; B, mandible; C, maxillule; D, maxilla.

\section{Megalopa (figs. 7-8)}

Very similar to that of other portunids. Rostral spine present. Eyes project as far as lateral margin of carapace. Carapace length (including rostrum) 1.69- 
$1.81 \mathrm{~mm}$, width 1.16-1.31 mm. Abdomen six-segmented, with dorso-ventrally flattened telson. Abdominal length (including telson) 1.31-1.35 mm. Total length including rostrum 3.00-3.2 mm.

Antennule (fig. 8A) with 3-segmented peduncle and two rami. Basal segment of peduncle bulbous. Inner ramus unsegmented, bears 3 distal and one inner lateral setae. Outer ramus 5-segmented: proximal segment without setae or aesthetascs, second to fourth segments bearing 15-18 aesthetascs arranged in 3 tiers, distal segment bears two plumose setae.

Antenna (fig. 8B) elongate, 11-segmented. Proximal segments comparatively larger and bearing simple setae. Eighth segment bears 4 setae on distal margin. Distal segment with 4 setae.

Mandible (fig. 7B). Simple cutting edge. Bears 3-segmented palp. Distal segment of palp broader, with 11-12 short plumose setae.

Maxillule (fig. 7C). Coxal and basal endites unsegmented. Coxal endite bears 4-5 proximal setae and 8-10 shorter distal setae. Basal endite has 17-20 setae of which 5-7 stout. Endopod 2-segmented. Proximal segment with 3 and distal segment with 1-2 setae.

Maxilla (fig. 7D). Both coxal and basal endites bilobed. Each lobe of coxal endite bears 3-4 terminal and 1-3 lateral setae. Each basal endite carries 9 to 12 setae of which a few are stout. Endopod reduced. Scaphognathite bears 58-60 plumose setae along outer margin.

First maxilliped (fig. 8C). Coxal and basal endites unsegmented, with many setae that serve for mastication. Endopod unsegmented, slightly expanded, with 4 setae on distal margin. Exopod 2-segmented, distal segment bears 5 terminal setae.

Second maxilliped (fig. 8D). Endopod 5-segmented. Distal two segments flattened, each bearing 7 to 10 setae, some stout and plumose. Exopod 2-segmented, distal segment smaller than proximal one, bearing 5 terminal setae.

Third maxilliped (fig. 8E) well developed. Endopod 5-segmented: first segment flattened, bearing 16-18, second segment 7-8 setae, respectively, along inner margin. Distal segment bears six terminal setae, two are longer and three setae are placed subterminally. Exopod 2-segmented, distal segment longer than proximal one, bearing 5-6 terminal setae. Coxa bears well-developed epipodite and gill.

First pereiopod (cheliped) (fig. 8F) 5-segmented, well developed. All segments bear a few short setae, mostly on propodus. Ischium and carpus each bear one short, stout spine.

Second to fifth pereiopods with well-developed endopods, each of 5 segments. Basis of second pereiopod bears spine on inner surface (fig. 8G). All segments of endopod bear a few short setae, most on last segment. One inner seta on propodus of second and third pereiopods is longer than the rest (fig. 8G, H), a character 


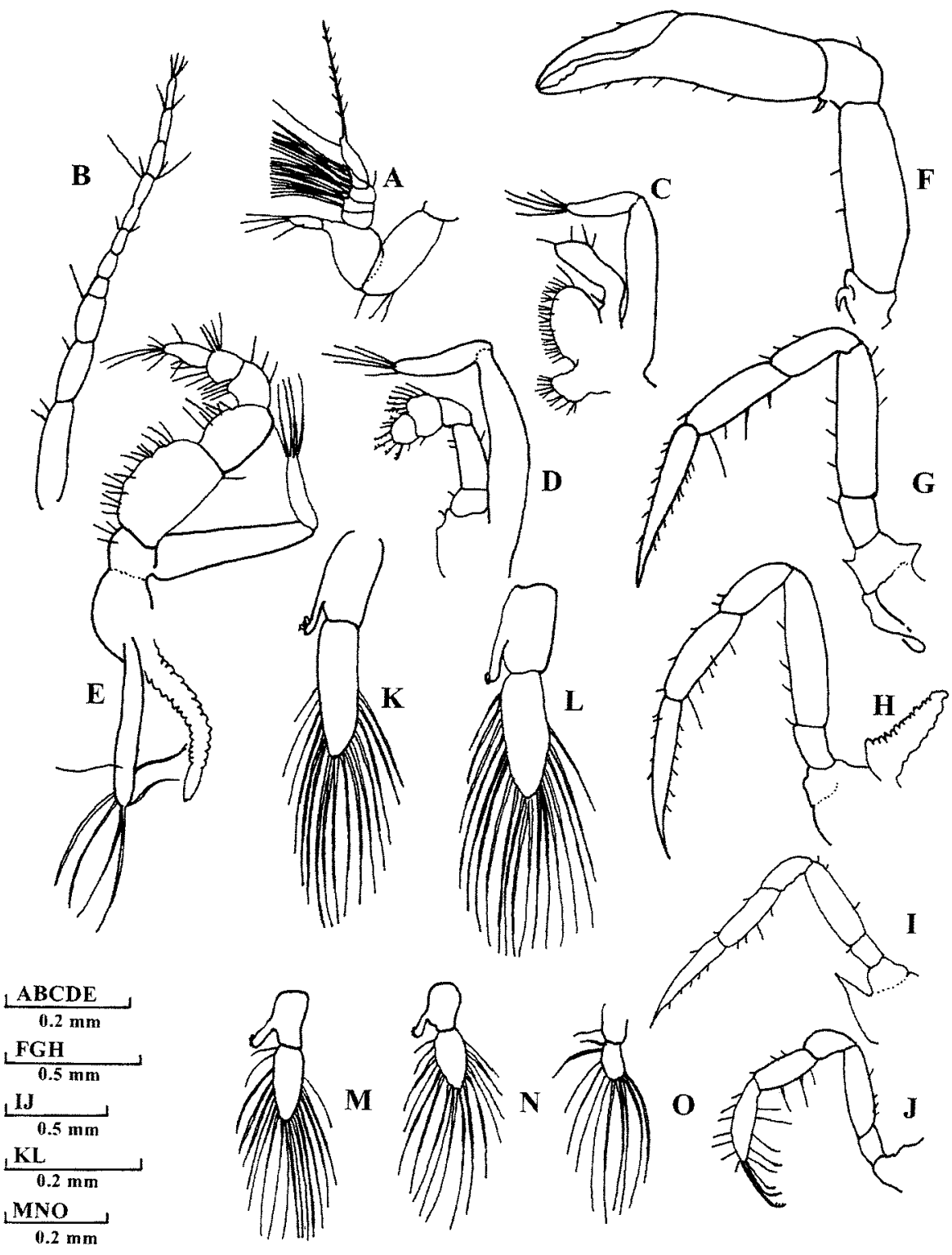

Fig. 8. Portunus pelagicus (Linnaeus, 1758), megalopa. A, antennule; B, antenna; C, first maxilliped; D, second maxilliped; E, third maxilliped; F, first pereiopod; G, second pereiopod; H, third pereiopod; I, fourth pereiopod; J, fifth pereiopod; K-N, second to fifth pleopods, respectively; O, uropod.

absent on the fourth pereiopod (fig. 8I). Dactylus of fifth pereiopod (fig. 8J) slightly flattened, bearing at its distal inner margin 6 to 7 long, hooked, modified setae. 
Pleopods (fig. 8K-N). First abdominal somite without pleopods, second to fifth with pleopods of similar structure. Exopods bear 15-20 plumose setae each. Endopod short, bearing 3-4 modified setae distally. Uropod (fig. 80) uniramous, bearing 11 plumose setae. Basis of uropod bears one long seta on inner margin.

\section{Crab stage}

The megalopa metamorphoses to crab instar I, which resembles the adult crab. Carapace width 2.0-2.5 mm. Margin of carapace serrated, with 9 anterolateral spines. Pereiopods well developed, with setae, especially on propodus and dactylus of fifth pair.

\section{DISCUSSION}

In Portunus pelagicus there are four zoeal stages and one megalopa stage. The megalopa metamorphosed directly into the first crab instar. In the present study, the total duration of larval development was 14-17 days. The first and second zoeal stages spanned 3-4 days each, the third and fourth stages 2-3 days each, and the megalopa 3-4 days. The first crab instar emerged in 15 to 18 days. According to reports of several workers, in most of the Portuninae the number of zoeal stages varies between 4 and 7. Many workers have reported the existence of five zoeal stages in Scylla serrata (Forskål, 1755) and each zoeal stage spanned 3-5 days (Ong, 1964; Brick, 1974; Haesman \& Fielder, 1983; Marichamy \& Rajapackiam, 1984, 1992; Marichamy, 1996; Anil, 1997; Kathirvel et al., 1997). In a closely related species, the American blue crab Callinectes sapidus Rathbun, 1896, Costlow \& Bookhout (1959) observed 7 zoeal stages. The complete larval development of Cancer magister Dana, 1852, Cancer irroratus Say, 1917, and Cancer gracilis Dana, 1852, has been reported by Poole (1966), Sastry (1970), Charmantier \& Charmantier (1991), and Ally (1975), respectively. All three species have five zoeal stages. For Thalamita crenata (Latreille, 1829) 5 zoeal stages are reported as well (Krishnan \& Kannupandi, 1990; Godfred et al., 1995). However, Greenwood \& Fielder (1979) observed that the megalopa stage in Portunus rubromarginatus (Lanchester, 1900) was reached in a minimum of 10 days after hatching and found that this species has only 3 zoeal stages, which is quite unusual among species of the Portuninae.

In India, there are no previous descriptions of the complete series of larval stages of Portunus pelagicus. Prasad \& Tampi (1953) described the first zoea of P. pelagicus (as Neptunus pelagicus) from laboratory-hatched larvae, but the descriptions of the later zoeal stages were from the plankton collection and not from laboratory hatching. Chhapgar (1956) described the megalopa of Portunus 
pelagicus (as Neptunus p.) from the Bombay coast. According to Bookhout \& Costlow (1974) "the larvae within the subfamily Portuninae are so similar, that it is very difficult to tell species apart from each other, than by examination of minute characteristics of those larvae which have been cultured from the egg". Raman et al. (1987) studied the larval development of $P$. pelagicus under laboratory conditions and found 3 zoeal stages and one megalopa stage. In the present study, it is very clear that there are four zoeal stages, and we disagree with the above conclusion. Those authors did not study the larval characteristics of each zoea, and perhaps they regarded zoea II and zoea III together as one stage. Delsman \& De Man (1925) described the freshly hatched early zoea of Portunus pelagicus (as Neptunus p.). Aikawa (1929) described the first zoea of the closely related species P. trituberculatus (Miers, 1876). The number of zoeal stages observed in the present study is in accordance with the works of Yatsuzuka (1962), Kurata \& Midorikawa (1975), and Shinkarenko (1979).

Prasad \& Tampi (1953) distinguished a pre-zoeal stage in the larval development of $P$. pelagicus. However, in the present study the newly hatched larvae were in first zoeal stage only: no pre-zoeal stage was observed in the hatchings. The authors (Prasad \& Tampi, 1953) also point out that these larvae assume all the characters of the first zoea in the course of about two hours, and they could not rear the larvae for more than twenty hours in the laboratory. Later stages reported are based on the zoeal collections from the wild, hence, with the exception of their description of the first zoea, the other details of the zoeal stages are unreliable.

Other workers have also reported a 'pre-zoeal' stage while rearing these crabs in the laboratory: Lebour (1928) in Necora puber (Linnaeus, 1767) (as Portunus p.), Davis (1965) in Callinectes sapidus, Ong (1964) in Scylla serrata, Ally (1975) in Cancer gracilis, and Andryszak \& Gore (1981) in Micropanope sculptipes Stimpson, 1859. Sandoz \& Hopkins (1944) and Sandoz \& Rogers (1944) suggested that the larvae hatched as pre-zoeae only under abnormal conditions, such as low salinity, or bacterial or fungal infection.

Lebour (1928), while discussing the primitive nature of brachyrhynchan larvae, considered the portunids as the most primitive because of their many zoeal stages and the structure of the spines on the telson. Costlow \& Bookhout (1959) and Costlow (1965) also suggested that the morphological variability found in the zoeal development of portunids is associated with the primitive nature of the family. According to Krishnan \& Kannupandi (1990), only within the Portunidae do any species occur with more than five zoeal stages, and for this reason it is considered to be the most primitive family within the Brachyura. The morphological variations encountered in the developmental stages of portunids may be a characteristic of the family. 
Larval morphology as described in the present work is comparable with that found by Shinkarenko (1979) in specimens from Australian waters, the only complete larval study on P. pelagicus available. As herein, Shinkarenko (1979) also reported four zoeal stages; however, variations can be observed in the pattern of setation on the various appendages. In the present study, the number of aesthetascs and setae on the antennule in the four zoeal stages are $2+0 / 2,5+0 / 1,4+2 / 1$, and $4+5 / 1$, respectively, in which aesthetascs are arranged in two groups, i.e., terminal and subterminal. Shinkarenko (1979) reported the antennular setae as $2+0 / 11$, $7+0 / 2,5+1 / 2$, and $5+4 / 2$, respectively. The descriptions of antenna, maxillule, and maxilla are similar in both works. The pattern of setation in first and second maxillipeds is different from the present work. In our material the number of setae on the exopods of these appendages is 4,4,5-6,12 and 4,8,10,12, respectively but in the work of Shinkarenko (1979) it was reported that the number of setae on the exopods of the first and second maxillipeds is the same, i.e., 4,8,10,14. Another important difference is the appearance of pleopod buds: in the present study the pleopod buds are visible only from the third zoeal stage, whereas Shinkarenko (1979) reported that pleopod buds are visible from the second zoeal stage onward. There is also disparity in the number of small setae present in the centre of the median curve of the telson in the $3^{\text {rd }}$ and $4^{\text {th }}$ zoeal stages. In the present work the numbers are 2 and 3, respectively, whereas Shinkarenko (1979) reports these as 3 and 4. The megalopal description is similar in both works, except for the segmentation of the endopod of the third maxilliped and the pereiopods. In the present observations, the endopods of these appendages are 5-segmented, whereas Shinkarenko (1979) described them as 6-segmented.

Stephensen (1972) suggested that Portunus pelagicus may be divided into clines and subspecies. The differences between the setal numbers of various appendages given by Shinkarenko (1979) and those found in the present study may be caused by the larvae reared in each study belonging to different subspecies, from two different, distant geographic locations.

The zoeal appendages show a wide variety; and the density and size of setae changes in each zoeal phase. The types of setae and their location on these appendages are both similar to those of Portunus spinicarpus (Stimpson, 1871) (cf. Bookhout \& Costlow, 1974) and can be related to the similar, carnivorous diet of these two species. In P. pelagicus, the abdomen of the zoea is very important in the capture of prey and also in holding the prey against the mouthparts. The serrated setae in the curve of the telson assist in the abrasion of the prey. Ong (1964) also found that the curvature of the abdomen aided in catching prey in suspension by the zoea of Scylla serrata, where the abdomen is also used to press the prey against the mouthparts. The zoea of $P$. spinicarpus also possesses serrated setae on the median curve of the telson. The function of the abdomen in prey capture, holding 
the prey against the mouthparts, and prey abrasion also applies to other carnivorous zoeae.

In the megalopal stage, the chelipeds are used for capturing prey, rather than the abdomen as in zoeal stages. The abdomen can no longer assist in prey capture and holding prey against the mouthparts, as it is reduced in size and more rigid, and because it bears pleopods. The telson is rounded and has lost the serrated setae used for prey abrasion in the zoea. The function of holding the prey to the mouthparts in the megalopa is carried out by the second and third maxillipeds instead. The endopods of these maxillipeds are large and well armed, with several serrated setae that help in breaking down the prey. The terminal segment of the second and third pereiopods of the megalopa bear serrated setae on the inner margin. These pereiopods also assist in holding the prey and in prey-abrasion. The coxal and basal endites of first maxillipeds are well developed, with many plumose setae for collecting and transferring the broken pieces of food towards the mouth.The mandibular palp also aids in transferring soft pieces of food into the mouth.

Ong (1964) described the larval stages of Scylla serrata, which occurs in much of the geographical range of Portunus pelagicus. Zoeae of these two species are similar in most respects, and to distinguish between them is difficult. Shinkarenko (1979) reported that in southeastern Queensland the first zoeae of the two species can be recognized by the number of aesthetascs of the antennule: P. pelagicus has two and $S$. serrata has three. This is in conformity with the present observations. From the present study, it is understood that Scylla zoeae can be distinguished from $P$. pelagicus by the examination of the exopods of the maxillipeds and the scaphognathite, the number of setae in these appendages differing considerably. Moreover, these are the easiest appendages to observe or to remove and, therefore, have the most practical value for identifying the species and determining the stage of any zoea.

\section{ACKNOWLEDGEMENTS}

The authors wish to express their sincere gratitude to the Director of the Central Marine Fisheries Research Institute, Cochin, for providing the facilities, and to the Head of the Crustacean Fisheries Division for support and encouragement. The first author is grateful to Dr. N. Neelakanta Pillai, Principal Scientist (Retd.), Crustacean Fisheries Division, CMFRI, Cochin, for his great help in the drawings of the larvae. 


\section{REFERENCES}

AikAwA, H., 1929. On the larval forms of some Brachyura. Rec. oceanogr. Wks Japan, 2: 17-55.

AlLY, J. R. R., 1975. A description of the laboratory reared larvae of Cancer gracilis Dana (Decapoda, Brachyura). Crustaceana, 28: 231-246.

Ameer Hams A, K. M. S., 1982. Observations on moulting of crab Portunus pelagicus Linnaeus reared in the laboratory. Journ. mar. biol. Ass. India, 24 (1-2): 69-71.

AndryszaK, B. L. \& R. H. Gore, 1981. The complete larval development in the laboratory of Micropanope sculptipes (Crustacea, Decapoda, Xanthidae) with a comparison of larval characters in western Atlantic xanthid genera. Fish Bull. Fish. Wildl. Serv. U.S., 79: 487-506.

ANIL, M. K., 1997. Studies on the fishery and culture prospects of mud crabs (genus Scylla De Haan) along the Kerala coast: 1-213. (Ph. D. Thesis, Cochin University of Science and Technology).

Bookhout, C. G. \& J. D. Costlow, JR., 1974. Larval development of Portunus spinicarpus reared in the laboratory. Bull. mar. Sci., 24: 20-51.

BRICK, R. W., 1974. Effects of water quality, antibiotics, phytoplankton and food on survival and development of larvae of Scylla serrata (Crustacea: Portunidae). Aquaculture, 3: 231-244.

Charnmantier-Daures, M. \& G. Charmantier, 1991. Mass culture of Cancer irroratus larvae (Crustacea, Decapoda): adaptation of a flow-through seawater system. Aquaculture, 97: 25-39.

СннаPGAR, B. F., 1956. On the breeding habits and larval stages of some crabs. Rec. Indian Mus., 54 (1): 33-52.

Costlow, J. D., JR., 1965. Variability in larval stages of the blue crab Callinectes sapidus. Biol. Bull., Woods Hole, 128: 58-66.

Costlow, J. D., JR. \& C. G. Bookhout, 1959. The larval development of Callinectes sapidus Rathbun reared in the laboratory. Biol. Bull., Woods Hole, 116: 373-396.

DAVIS, C. C., 1965. The study of the hatching process in aquatic invertebrates. XX. The blue crab, Callinectes sapidus Rathbun. XXI. The nemertean, Carcinonemertes carcinophila (Kölliker). Chesapeake Sci., 6: 201-208.

Delsman, H. C. \& J. G. DE MAn, 1925. On the "Radjungans" of the Bay of Batavia. Treubia, 6: 308-323.

Godfred, J., A. Veera RaVi \& T. Kannupandi, 1995. Seed production of the edible estuarine portunid crab Thalamita crenata (Latreille). Journ. Aquac. trop., 10: 213-219.

Greenwood, J. G. \& D. R. FIELDER, 1979. The zoeal stages and megalopa of Portunus rubromarginatus (Lanchester) (Decapoda: Portunidae) reared in the laboratory. Journ. Plankton Res., 1 (2): 191-205.

HAesman, M. P. \& D. R. FieldeR, 1983. Laboratory spawning and mass rearing of the mangrove crab, Scylla serrata (Forskål), from first zoeal to first crab stage. Aquaculture, 34: 303-316.

Kathirvel, M., S. Sriminasagam, P. K. Ghose \& C. P. Balasubramanian, 1997. Mud crab culture. Fishing Chimes, 17 (6): 28-33.

KRISHNAN, T. \& T. KANNUPANDI, 1990. Laboratory cultured zoeae, megalopa and first crab of the estuarine crab Thalamita crenata (Latr.) A. Milne-Edwards, 1861 (Brachyura: Portunidae). Mahasagar, 23 (2): 139-152.

KurATA, H. \& T. MidORIKAWA, 1975. The larval stages of the swimming crab, Portunus pelagicus and P. sanguinolentus reared in the laboratory. Bull. Nansei reg. Fish. Res. Lab., 8: 29-38.

Lebour, M. V., 1928. The larval stages of the Plymouth Brachyura. Proc. zool. Soc. London, 1928: 473-560.

MARICHAMY, R., 1996. Mud crab culture and hatchery. Bull. centr. mar. Fish. Res. Inst., Kochi, India, 48: 103-107.

MARICHAMY, R. \& S. RAJAPACKIAM, 1984. Culture of larvae of Scylla serrata. Mar. Fish. Inform. Serv., (Techn. Ext.) 58: 13-15. 
— — \& — - 1992. Experiments on larval rearing and seed production of the mud crab Scylla serrata (Forskål). In: C. A. ANGELL (ed.), Report on the seminar on the mud crab culture and trade, Surat Thani, Thailand Nov. 5-8, 1991. Bay of Bengal Programme Reprints, 51: 135-141.

ONG, K. S., 1964. The early developmental stages of Scylla serrata (Forskål) (Crustacea, Portunidae), reared in the laboratory. Proc. Indo-Pacific Fish. Counc., 11 (2): 135-146.

Poole, R. L., 1966. A description of laboratory reared zoeae of Cancer magister Dana, and megalopae taken under natural conditions (Decapoda, Brachyura). Crustaceana, 11: 83-97.

PRASAD, R. R. \& P. R. S. TAMPI, 1953. A contribution to the biology of the blue swimming crab, Neptunus pelagicus (Linnaeus) with a note on the zoeae of Thalamita crenata Latreille. Journ. Bombay nat. Hist. Soc., 51: 674-689.

Raman, K., S. SRinivasagam, C. P. Rangaswamy, S. Krishnan, K. O. Joseph \& M. SulTANA, 1987. A note on larval rearing of the edible crab, Portunus pelagicus (Linnaeus), at Ennore hatchery, Madras. Indian Journ. Fish., 34 (1): 128-131.

SAndoZ, M. \& S. H. Hopkins, 1944. Zoeal larvae of blue crab, Callinectes sapidus Rathbun. Journ. Washington Acad. Sci., 34: 132-133.

SANDOZ, M. \& R. Rogers, 1944. The effect of environmental factors on hatching, moulting and survival of zoea larvae of the blue crab Callinectes sapidus Rathbun. Ecology, 25: 216-228.

SASTRY, A. N., 1970. Culture of brachyuran crab larvae using a re-circulating sea water system in the laboratory. Helgoländer wiss. Meeresunters., 20: 406-416.

ShinkarenKo, L., 1979. Development of the larval stages of the blue swimming crab Portunus pelagicus L. (Portunidae: Decapoda: Crustacea). Australian Journ. mar. freshw. Res., 30: 485503.

StePHENSON, W., 1972. An annotated check list and key to the Indo-west-Pacific swimming crabs (Crustacea: Decapoda: Portunidae). Roy. Soc. New Zealand Bull., 10: 1-64.

YATSUZUKA, K., 1962. Studies on the artificial rearing of the larval Brachyura especially on the larval blue crab Neptunus pelagicus Linnaeus. Rep. U.S.A. mar. biol. Sta., Kochi University, 9: $1-88$.

First received 9 January 2003.

Final version accepted 15 March 2004. 